\title{
EL RETRATO DE DONAN'TES Y EL AUTORRETRATO EN LA PINTURA NOVOHISPANA
}

\author{
NOTAS PARA EL ESTUDIO DE LA PINTURA COLONIAL DE RETRATO *
}

\section{Eutsa VARgas Lugo}

Los estudios sobre la pintura colonial de retrato comienzan apenas a hacerse. La dispersión que han sufrido estas obras, los retoques, el anonimato de la mayor parte de ellas, pero sobre todo, la preponderancia que tuvo la pintura de tema religioso, hicieron que por mucho tiempo la mayor atención se dedicara a esta última que constituye sin duda, el núcleo fundamental, la creación más brillante y trascendental de la pintura novohispana.

En otros artículos ${ }^{1}$ ya he expresado que, desde mi punto de vista, los cánones que rigieron a la pintura religiosa influyeron de manera definitiva en la pintura de tetrato, puesto que, para empezar, el hombre -de acuerdo con la filosofia del tiempo- no exa objeto de arte, por lo cual la pintura de retrato no pudo existir como especialidad y después, porque los pintores, que estaban incondicionalmente al servicio de la Iglesia, eran, antes que nada, pintores de temas religiosos, que pintaron retrato con una prepaxación inadecuada, puesto que, por lo que hasta ahora se conoce, los retratos fueron pintados por los mismos artistas que representaron los temas religiosos. Existe un caso sin embargo que, por lo menos hasta ahora, parece ser excepción. Se trata del pintor Ignacio Ma. Barreda de quien se conocen ya bastantes retratos y en cambio, que yo sepa, ninguna obra de tema religioso. Este artista floreció ya a fines del siglo xvıII y esto puede explicar, en parte, el hecho de que hubiexa podido dedicarse, preferentemente al género de retrato, dado que la influencia del arte neoclásico era por entonces bastante considerable.

El entrenamiento de los pintores coloniales en la constante expresión de temas sagrados; de los valores intangibles e invisibles de la espiri-

* Parte de un trabajo en elaboración.

1 "La expresión pictórica religiosa y la sociedad colonial". Anales del Instituto de Investigaciones Estéticas, UNAM, 1981, En prensa, y "Una aproximación al estudio del retrato en la Nueva España", Libro de Homenaje al doctor Enrique Marco Dorta. En prensa en España. 
tualidad religiosa; la búsqueda de un ideal de belleza sagrada, influyeron definitivamente en la expresión de la pintura de retrato, hicieron que ésta se estereotipara y que los artistas se avinieran a reproducir el natural, sin particularizar, sino más bien generalizando. Por estas razones --mencionadas aquí escuetamente- puede decirse que en el retrato novohispano, en general, no se persiguió la apariencia de perfección física exaltada por la belleza idealista o académica, ni tampoco sencillez o naturalidad, ni realismo estricto. Son en cambio obras que estilísticamente resultan convencionales en alto grado; que en muchas ocasiones se acercan a un realismo bastante fiel y vigoroso y otras se alejan demasiado de él, porque -en sentido estricto- no se pretendió pintar los retratos como apariencias existenciales, sino más bien como testimonios documentales.

El retrato novohispano tampoco muestra un expresionismo libre, sino que su expresión es contenida, demasiado sobria, demasiado formal y cayó en soluciones rutinarias como puede verse en la composición, postura y elementos secundarios que caracterizan a los retratos masculinos y femeninos de la época. Por estas mismas razones -en los siglos Xi'II y XVIII-, el carácter sensorial que aparece en las formas inanima. das del estilo barroco, está ausente de los retratos que se produjeron en su tiempo pues casi nunca muestran sensualidad, ni en los rostros y mucho menos en los cuerpos que aparecen siempre cubiertos totalmente por los lujosos ropajes civiles o religiosos; de ahí el estático recato, precisamente antinatural que, salvo raras excepciones, resalta como característica fundamental y general de este género de obras. Otra característica igualmente importante y aparente, es el tratamiento que se da al rostro de los modelos retratados: tendencia a generalizar las facciones -por lo general de trazo duro-y piel lisa, tan tersa que no parece tener poros y que no presenta las características propias del sexo y de las edades. La mirada -centro de la expresión-es casi siempre quieta, severa, en muchos casos inexpresiva y rara vez elocuente, sobre todo en los retratos de auto. ridades eclesiásticas y civiles, en los que parece deliberado el efecto de ausentismo que ofrecen los rostros, posiblemente en un deseo de comunicar espiritualmente el retrato.

En términos generales éstas son pues, por ahora, las características del retrato novohispano que pueden señalarse como determinantes, incluyendo las representaciones de niños, y de mujeres, salvo, como se ha dicho, algunas notables excepciones. 


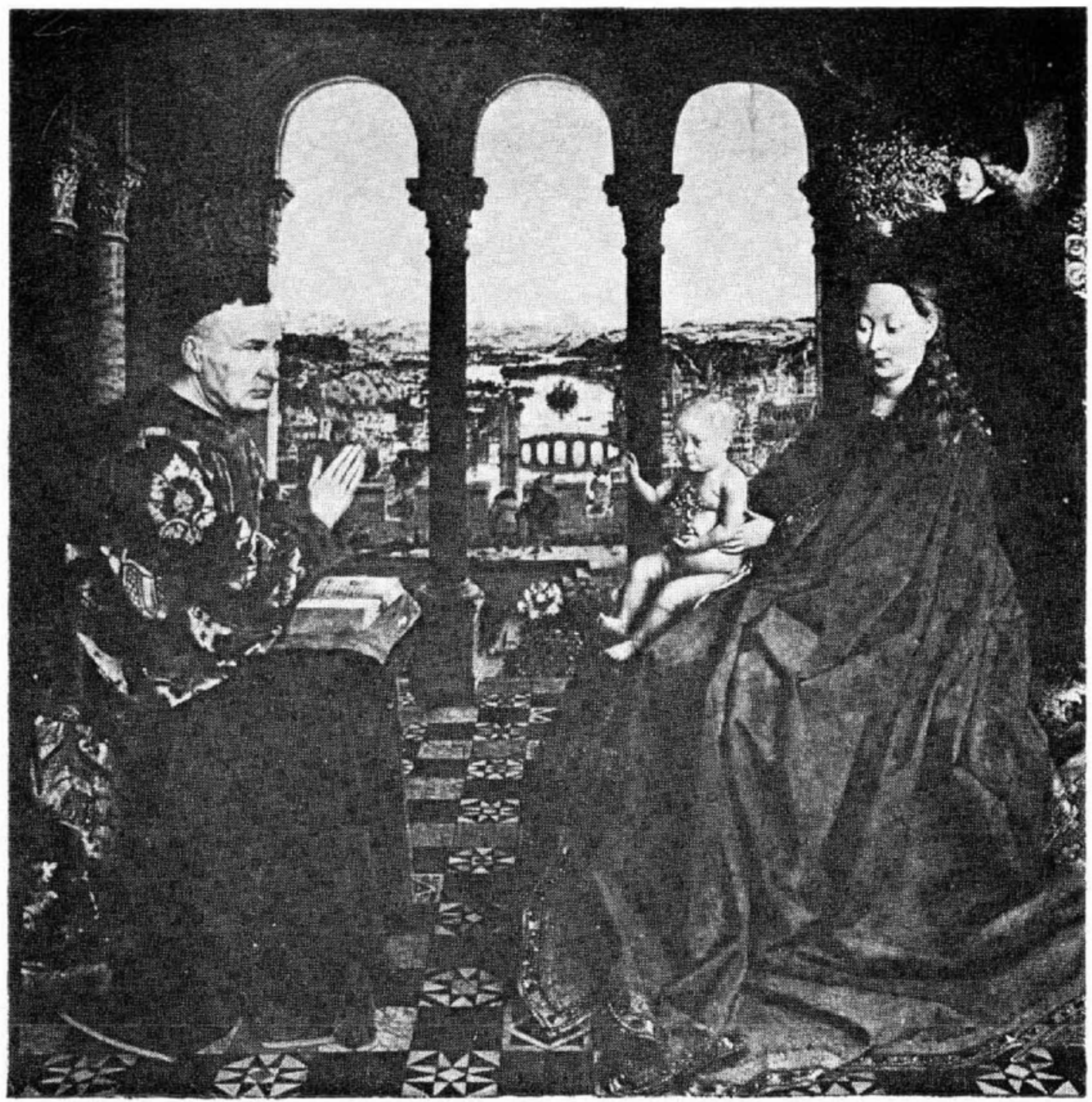

rigura 1. Virgen de Autun. Juan van Eyck, 1425-35. Xvir. 
DOI: http://dx.doi.org/10.22201/iie.18703062e.1983.51.1172

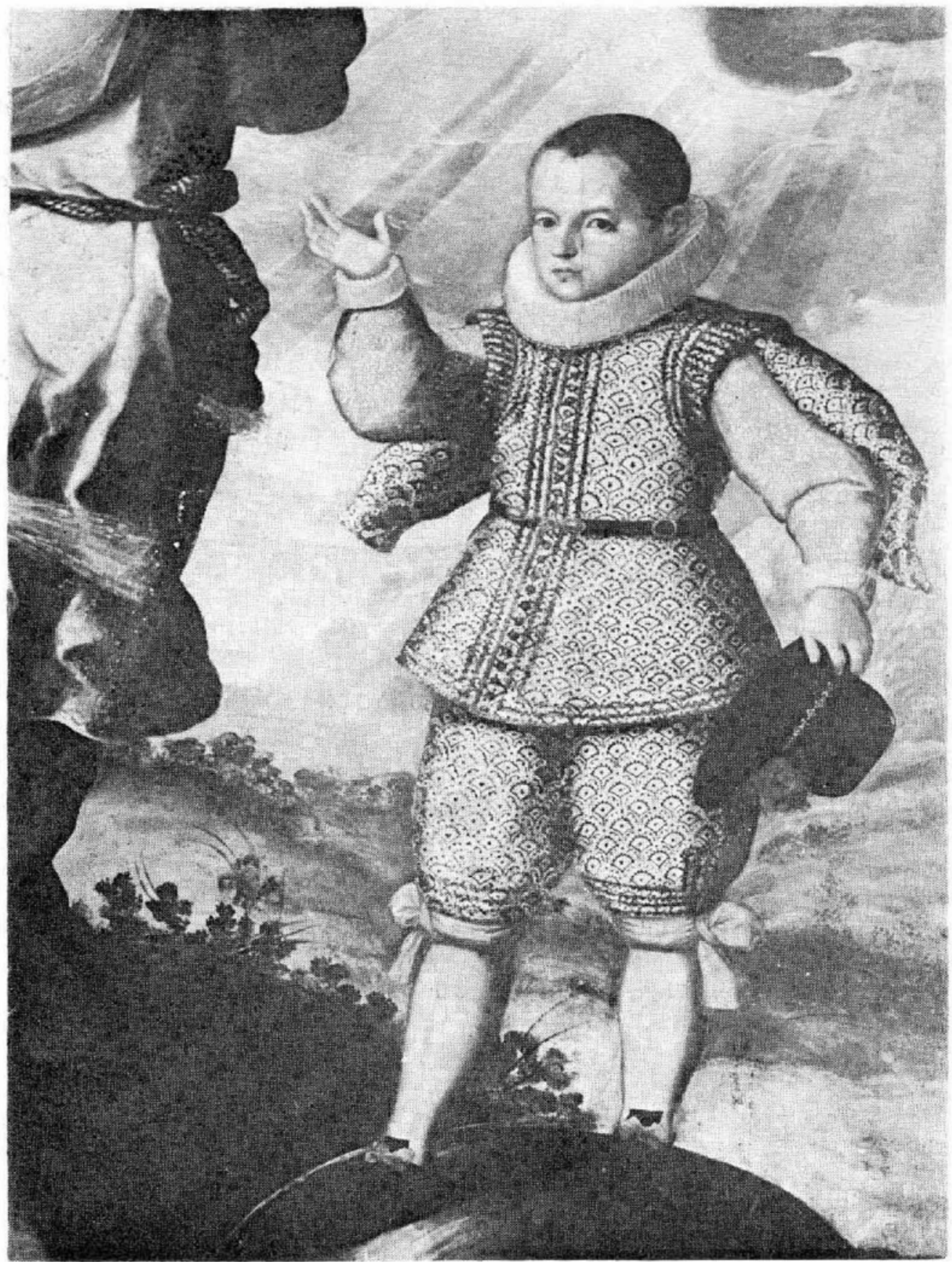

Figura 2. Niño donante. Pormenor del Angel de la Guarda. Atribuido a Luis Juárez. xvir. Pinacoteca Virreinal. 
DOI: http://dx.doi.org/10.22201/iie.18703062e.1983.51.1172

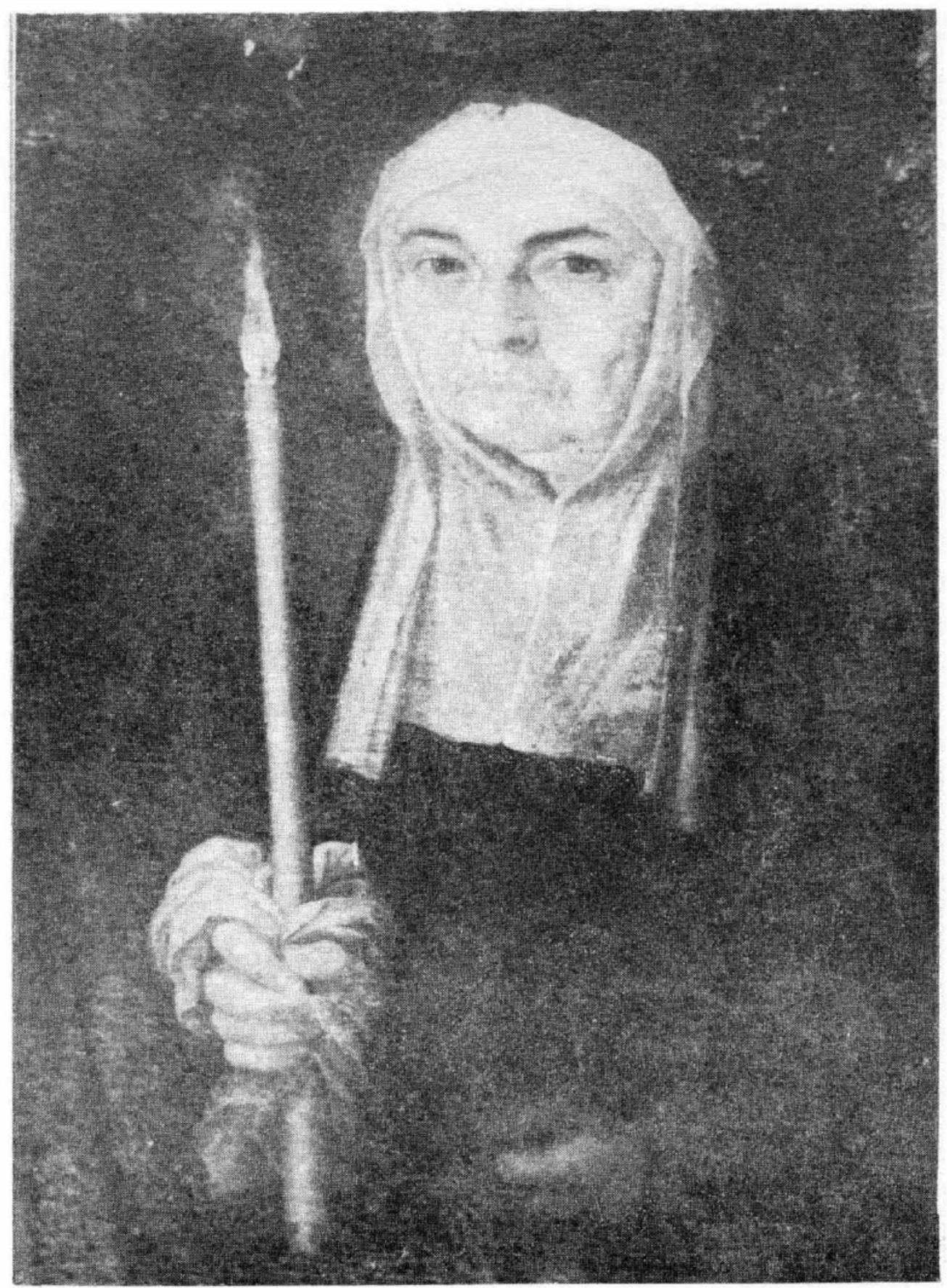

Figuīa ¿. Anciana donante. Pormenor de Imposición de la casulla a San Ildefonso. Anónimo. XvII. 
DOI: http://dx.doi.org/10.22201/iie.18703062e.1983.51.1172

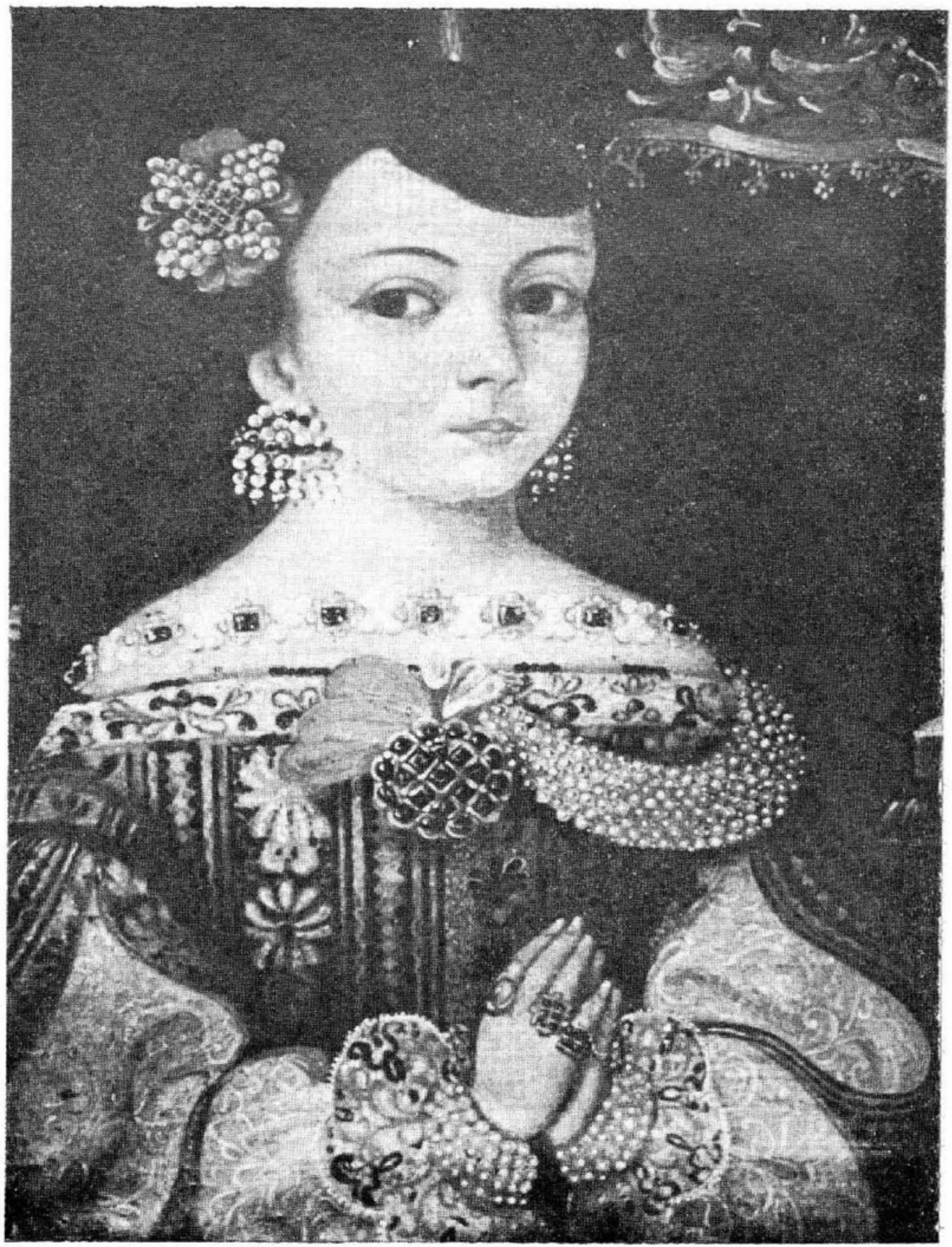

Figura 4. Niña donante. Virgen del Patrocinio de Zacatecas. Juan Correa. xvir. Museo de Guadalupe, Zac. 
DOI: http://dx.doi.org/10.22201/iie.18703062e.1983.51.1172

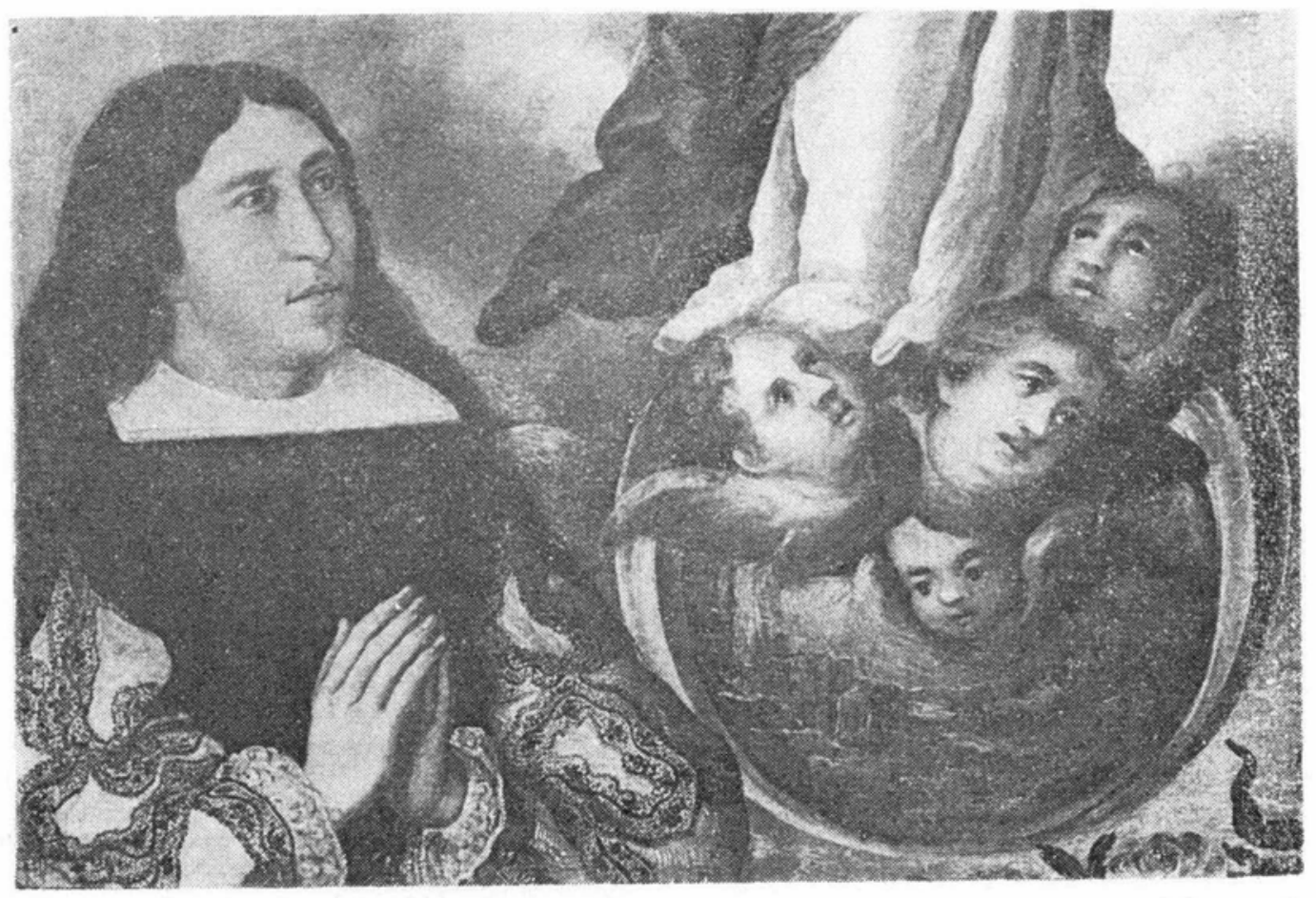

Figura 5. Donante. Pormenor de la Tota Pulchra de Juan Correa. xvir. Museo de Churubusco. 
DOI: http://dx.doi.org/10.22201/iie.18703062e.1983.51.1172

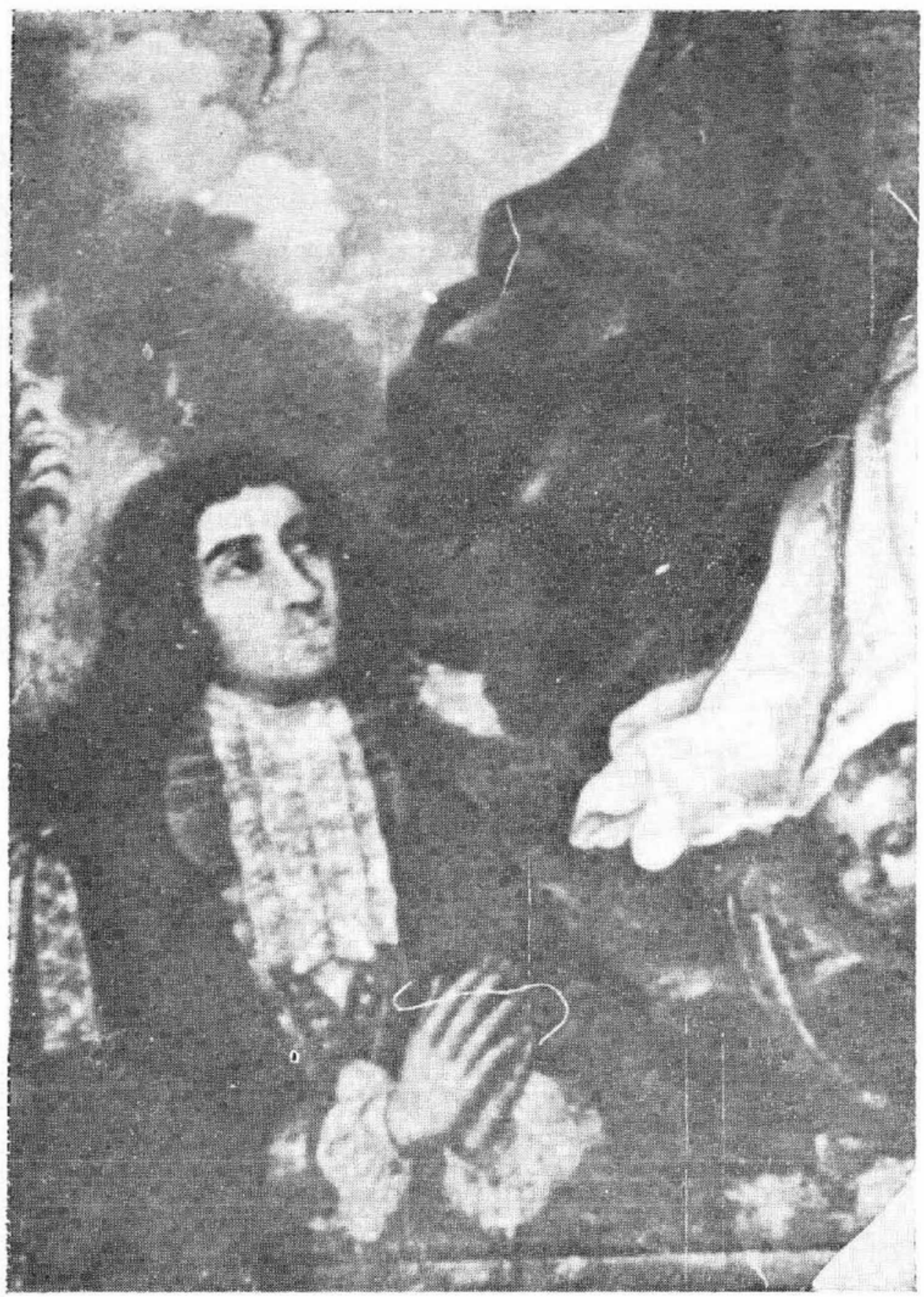

Figura 6. Donante. Pormenor de La Inmaculada de Juan Correa, xvrr. Tudela, España. 


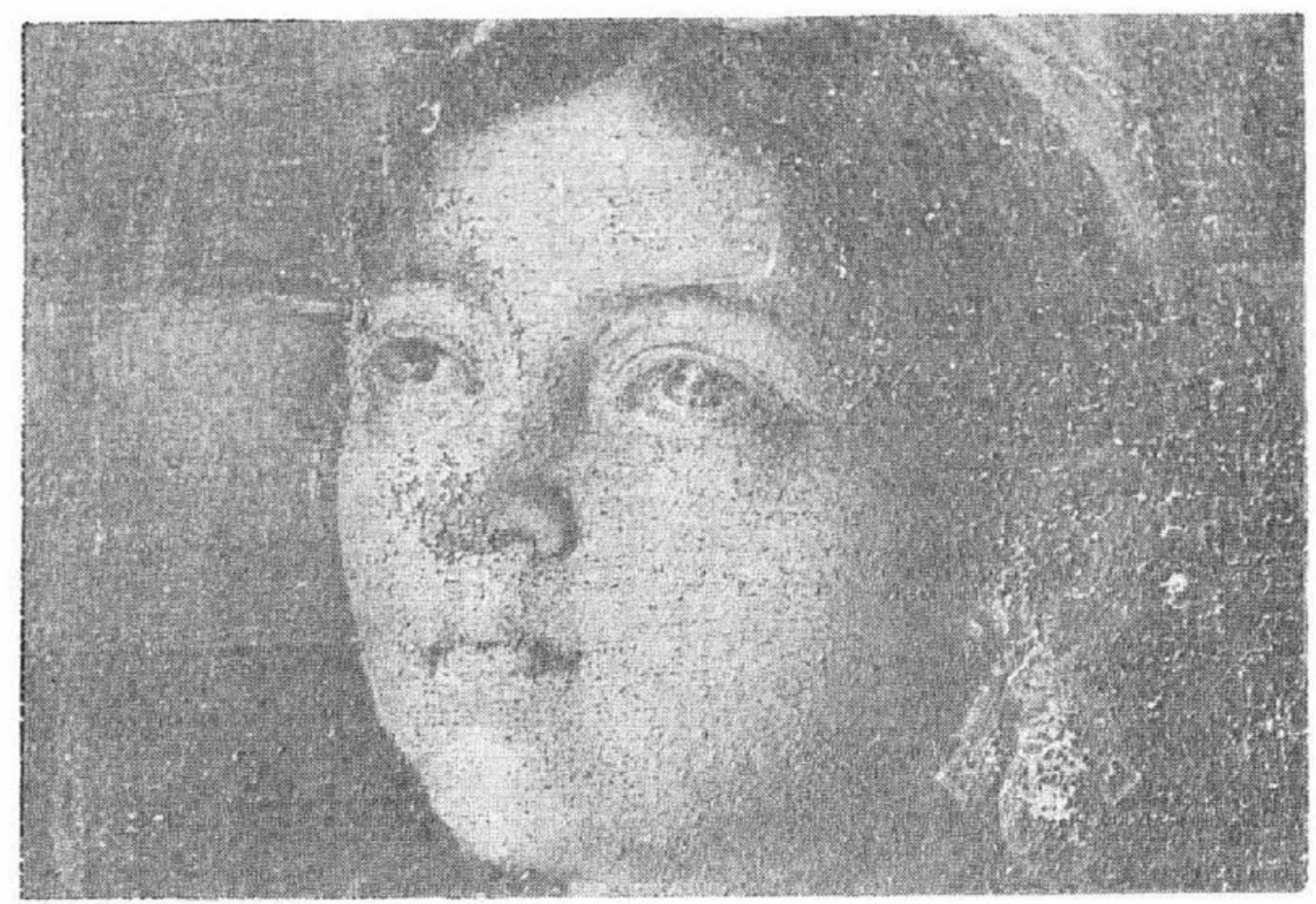

Figura 7. Niña mestiza donante. Pormenor de la pintura San Antonio de Padua. xvit. Antonio Rodríguez. 


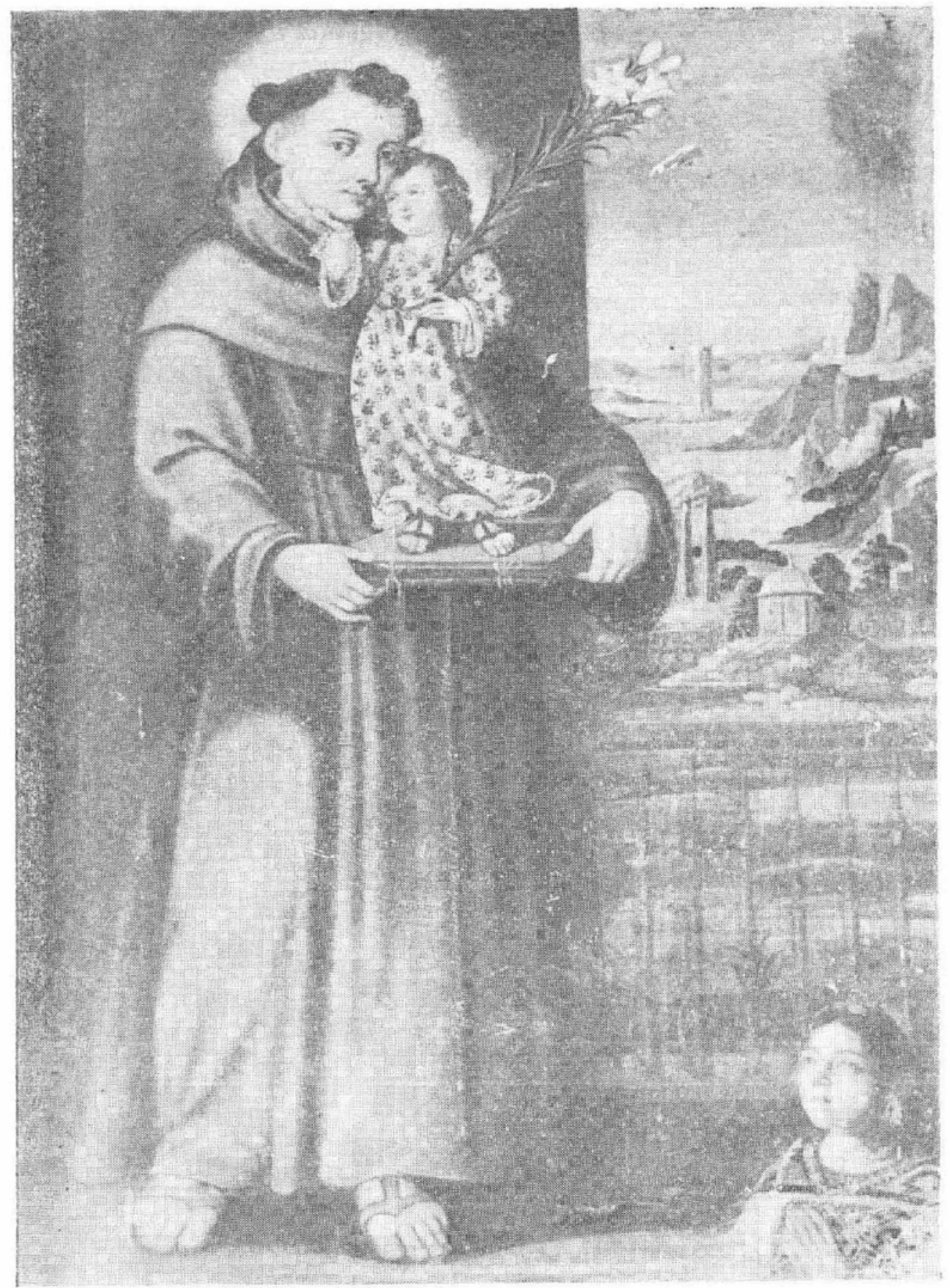

Figura 8. San Anionio de Padua. Atribuido a Antonio Rodríguez. xvII. 


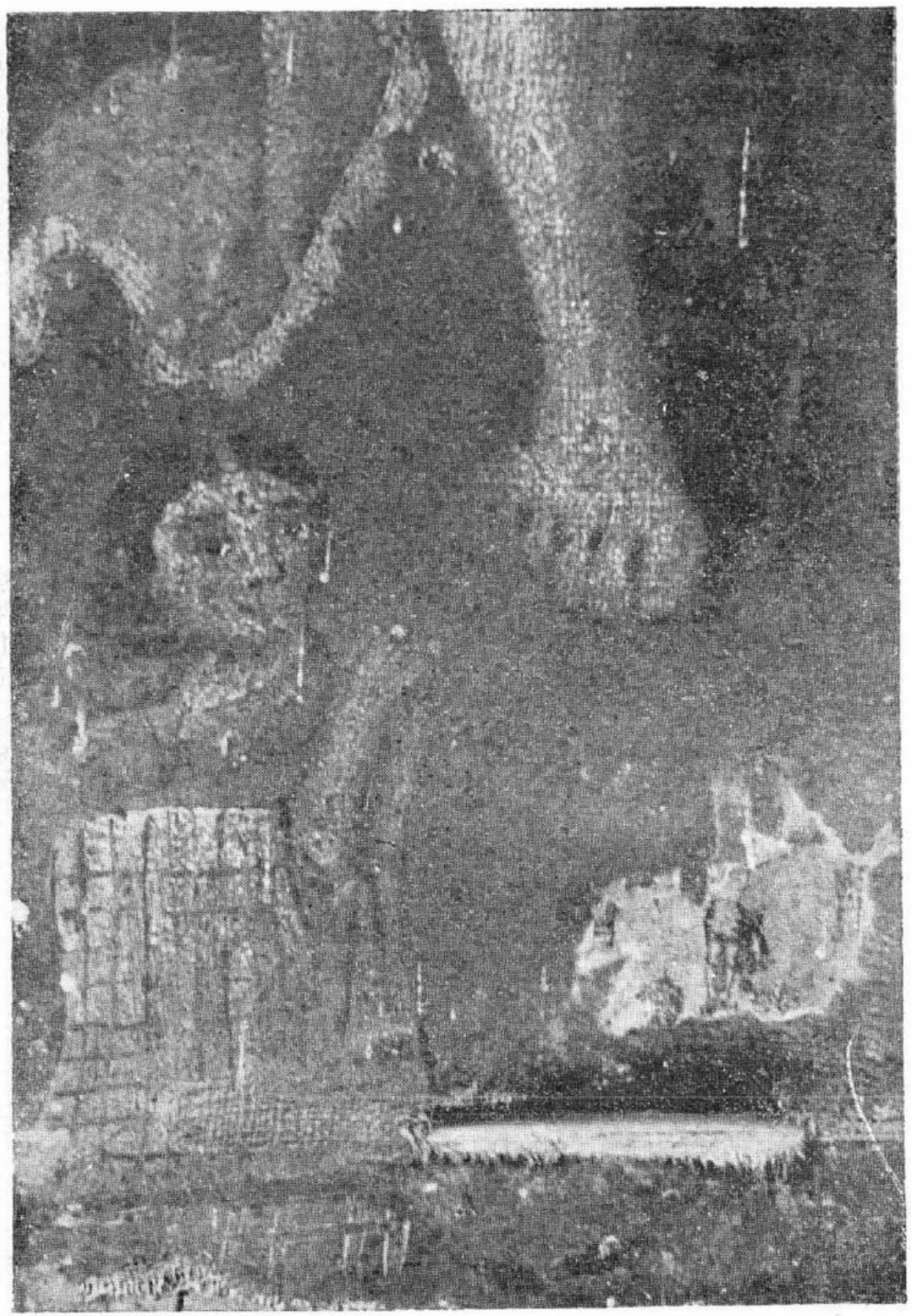

Iigura 9. Niña india donante. Pormenor de Santa Rosa de Lima con San Juan Bautista. Anónimo. 
DOI: http://dx.doi.org/10.22201/iie.18703062e.1983.51.1172

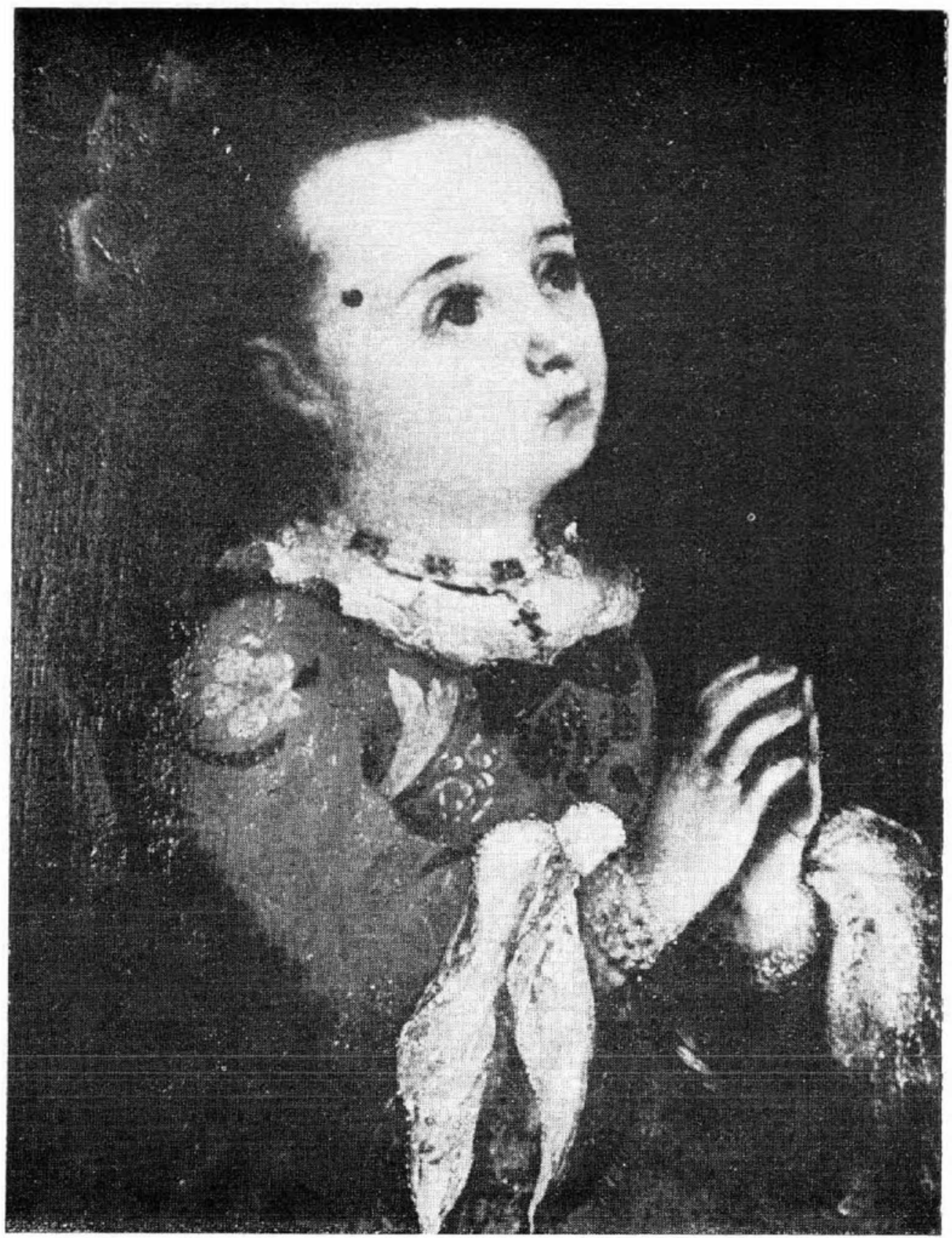

Figura 10. Niña donante. Pormenor de Santa Ana enseñando a leer a la Virgen. Nicolás Rodrígucz Juárez. xvilı. Museo de Guadalajara, Jal. 
DOI: http://dx.doi.org/10.22201/iie.18703062e.1983.51.1172

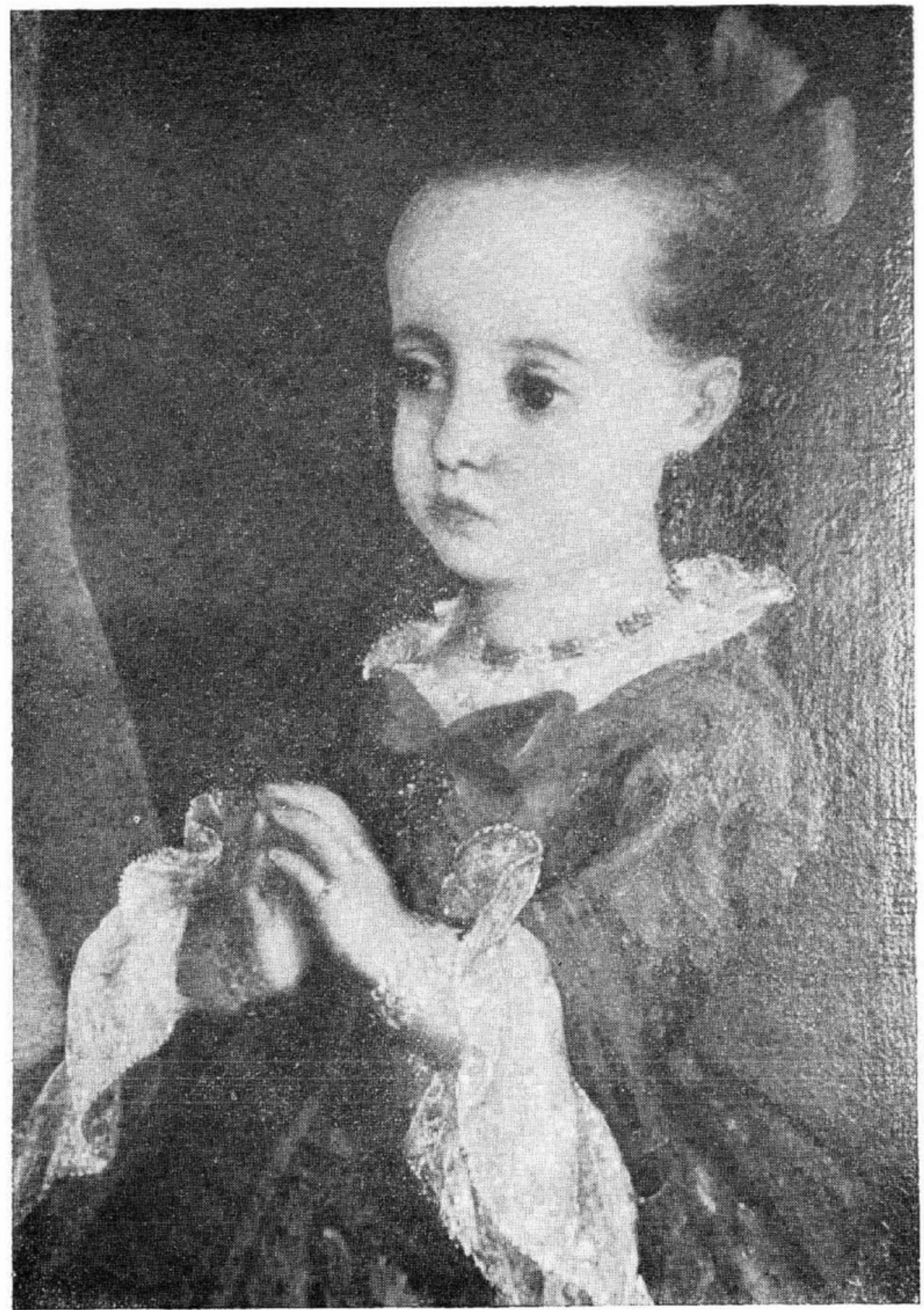

Figura 11. Niña donantc. Pormenor de Santa Ana enseriando a leer a la Virgen. Nicolás Rodriguez Juárez. xvir. Museo de Guadalajara, Jal. 
DOI: http://dx.doi.org/10.22201/iie.18703062e.1983.51.1172

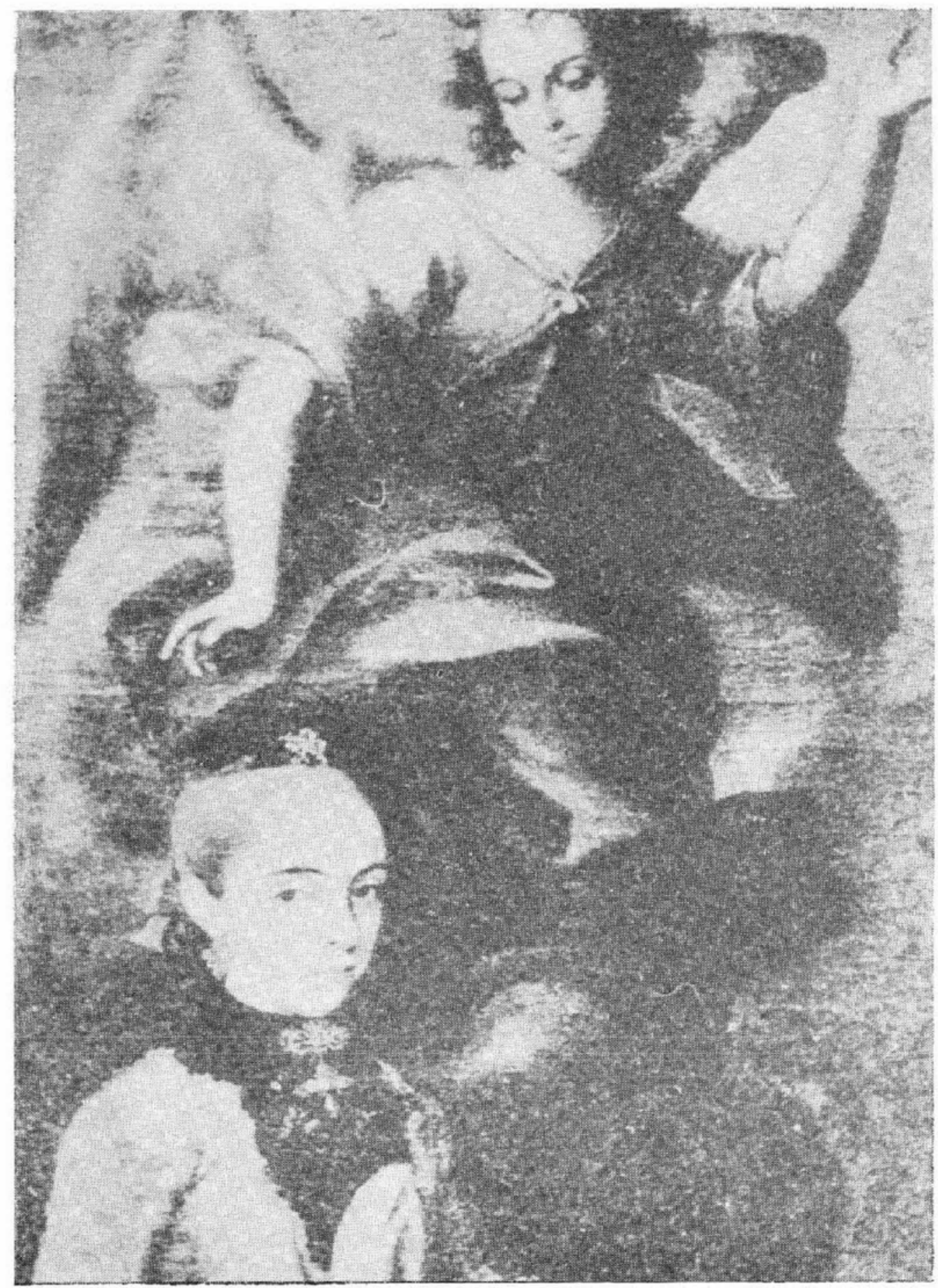

Figura 12. Joven donante con ángel de la guarda. Mignel Cabrera. Xril. 


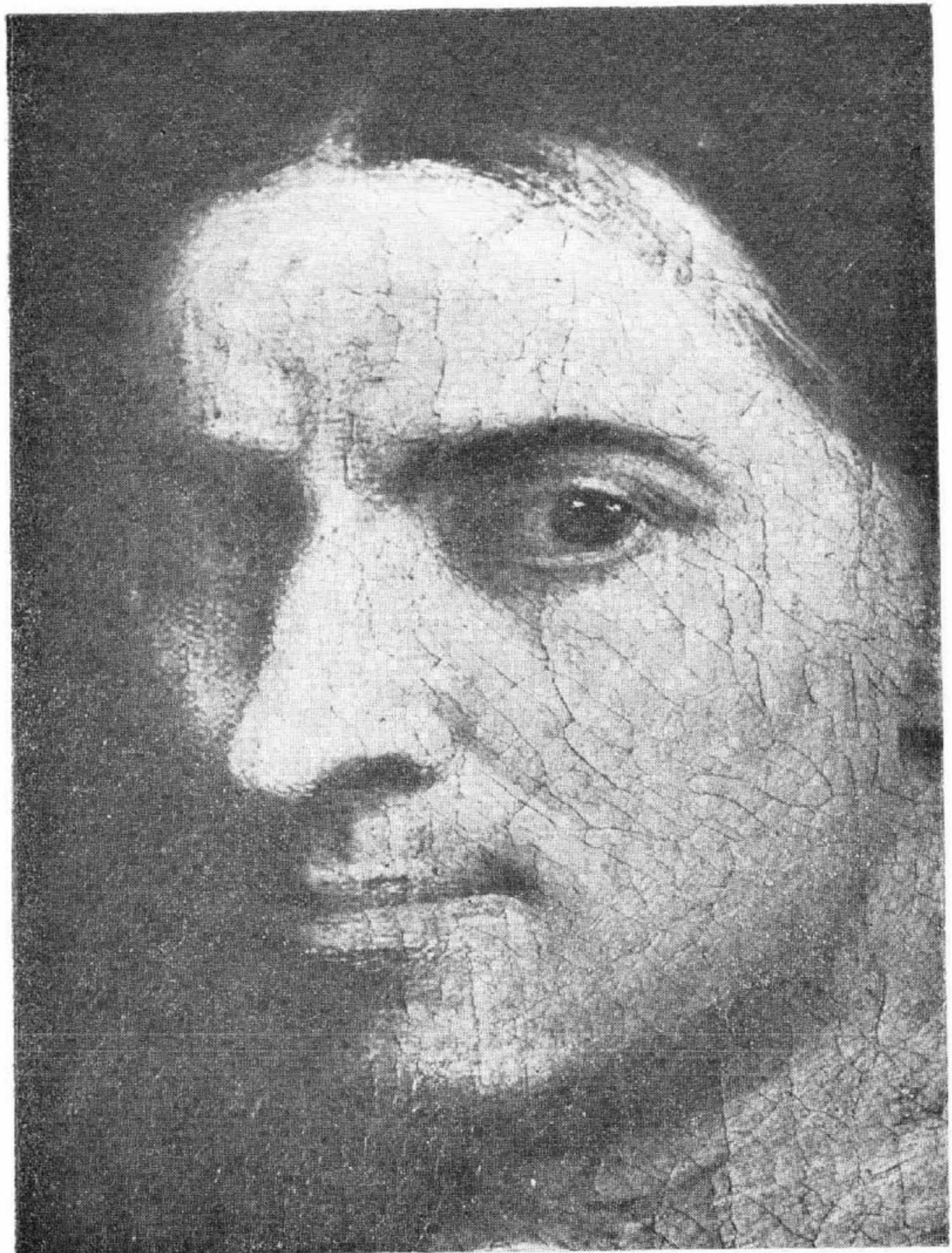

Figura 13. Pormenor del autorretrato de Juan Rodriguez Juárez. Activo entre 1692. 1728. Pinacoteca Virreinal. México, D. F. 
DOI: http://dx.doi.org/10.22201/iie.18703062e.1983.51.1172

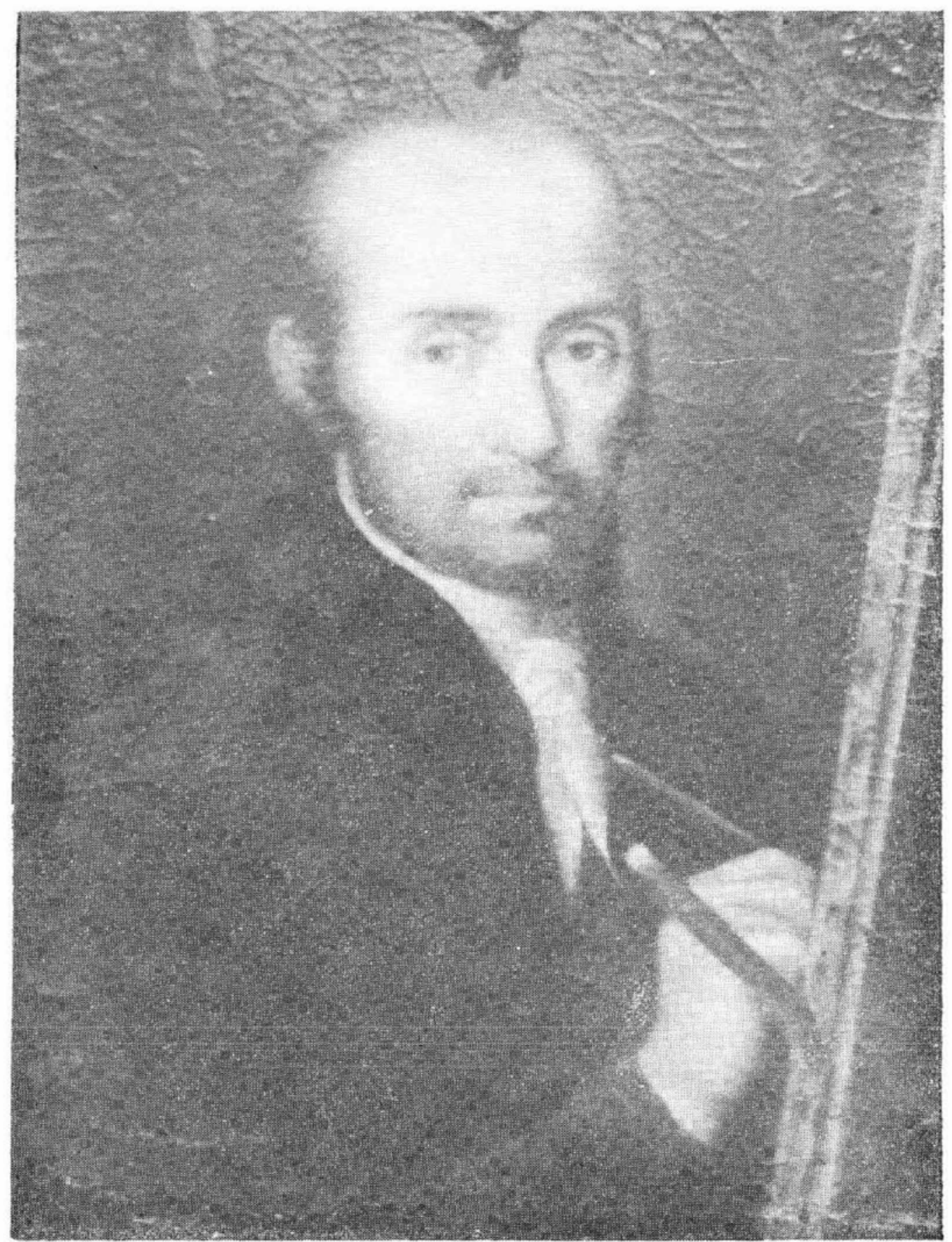

Figura 14. Autorretrato. Miguel Cabrera o José de Ibarra?. xvin. Pinacoteca Virreinal. 
DOI: http://dx.doi.org/10.22201/iie.18703062e.1983.51.1172

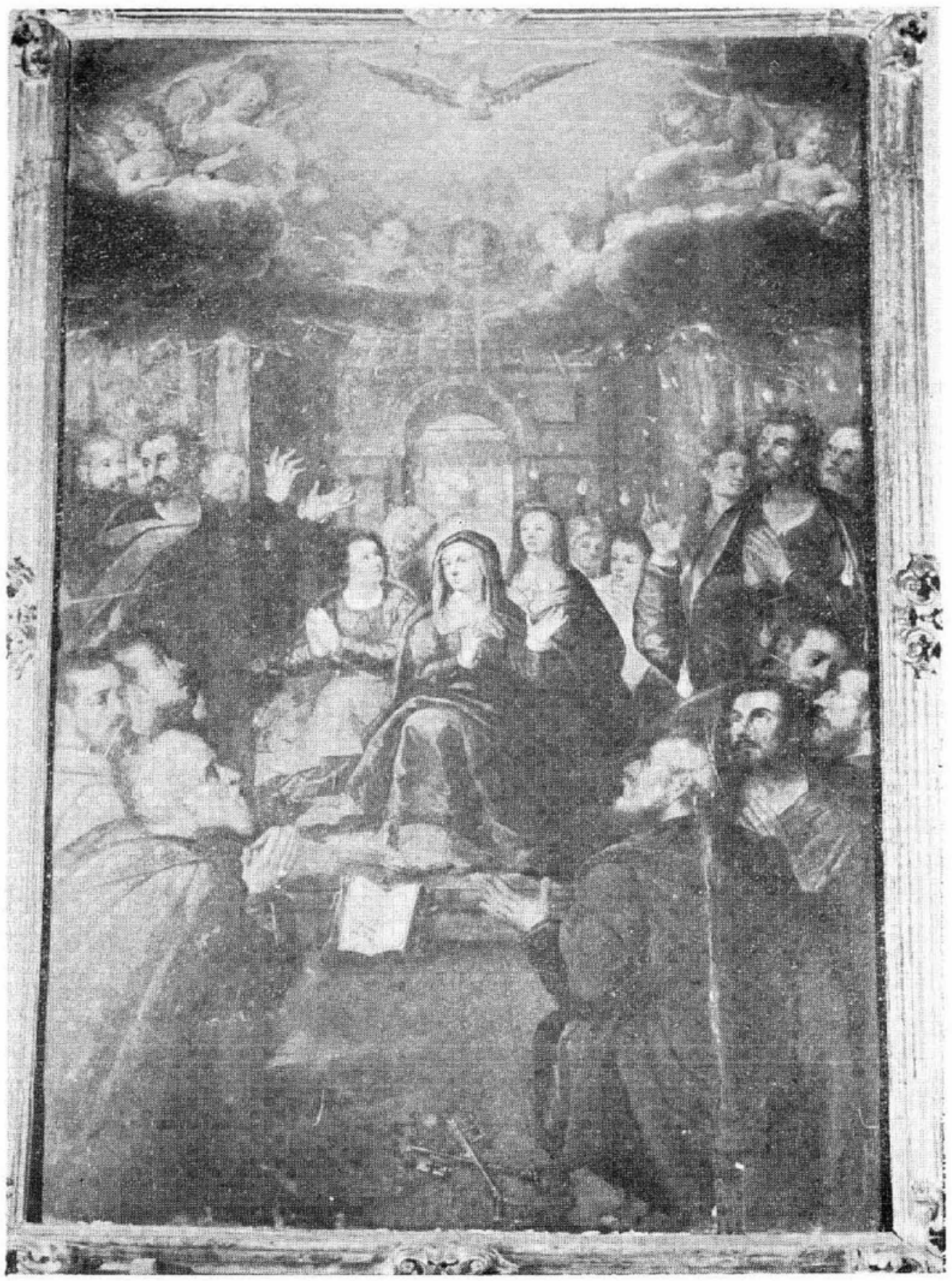

Figura 15. Autorretrato de Baltazar de Echave Orio en su pintura Fentecostés. Galerias del templo de la Profesa. México, D. F. 


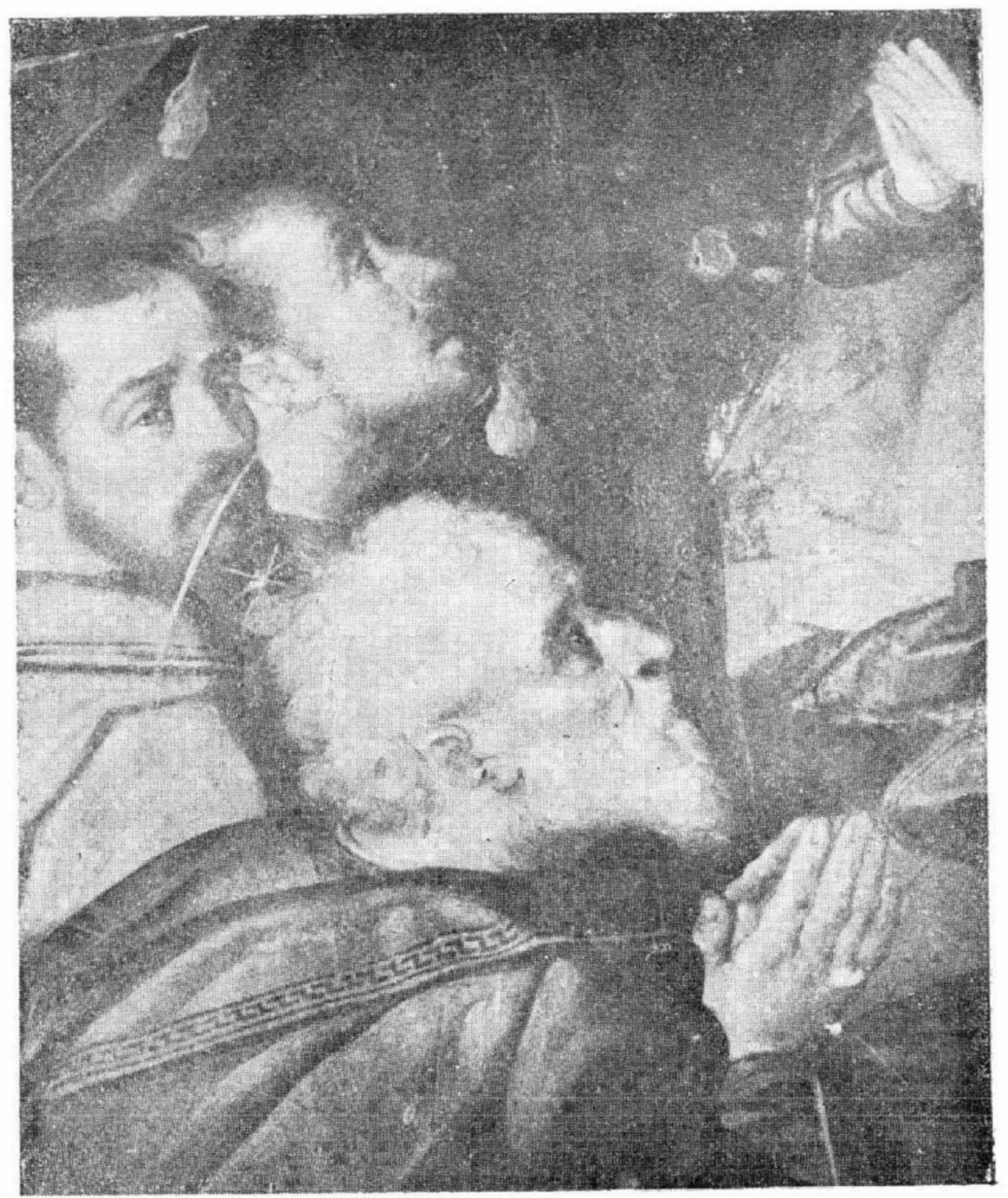

Figura 16. Pormenor de la obra anterior. 
DOI: http://dx.doi.org/10.22201/iie.18703062e.1983.51.1172

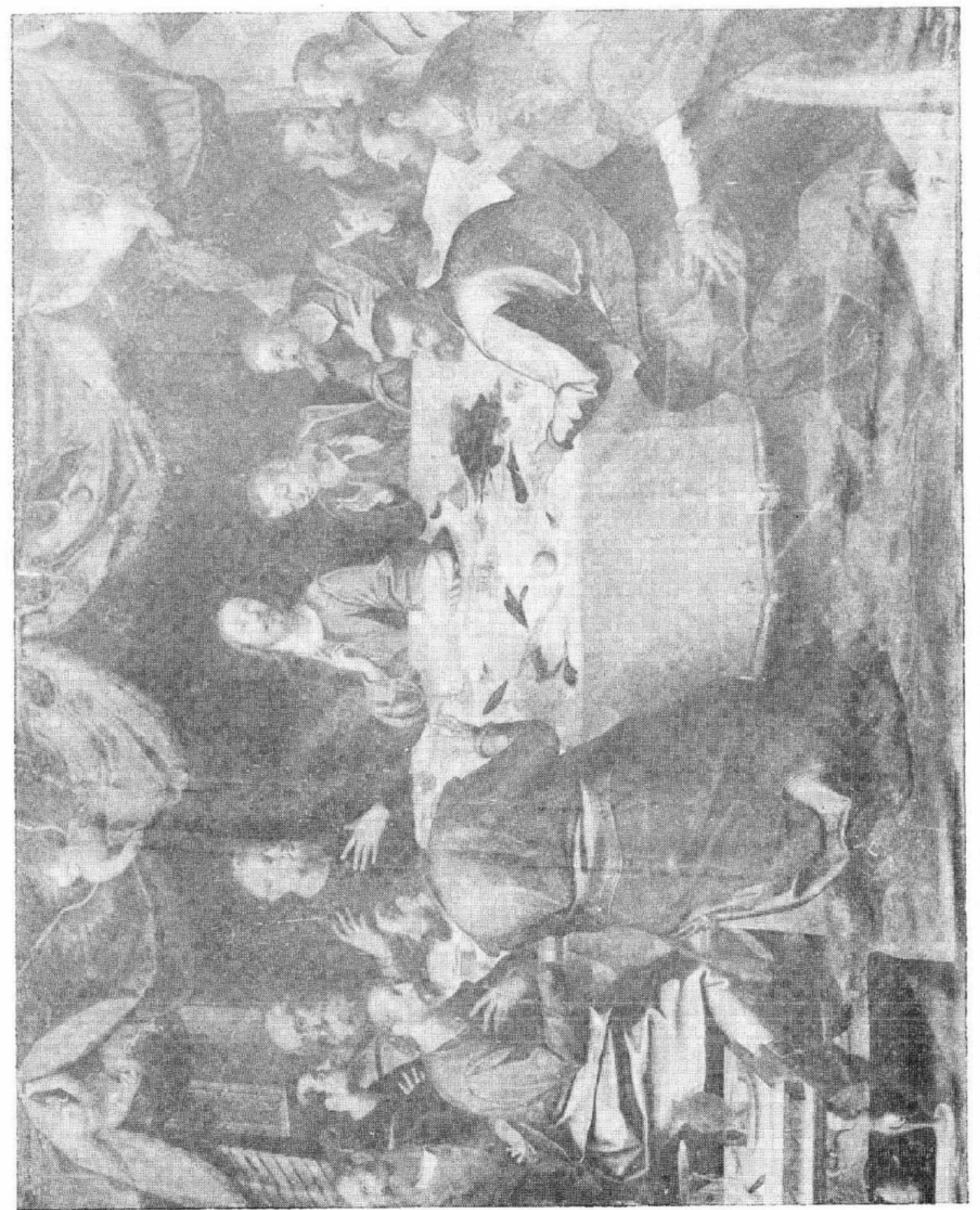


DOI: http://dx.doi.org/10.22201/iie.18703062e.1983.51.1172

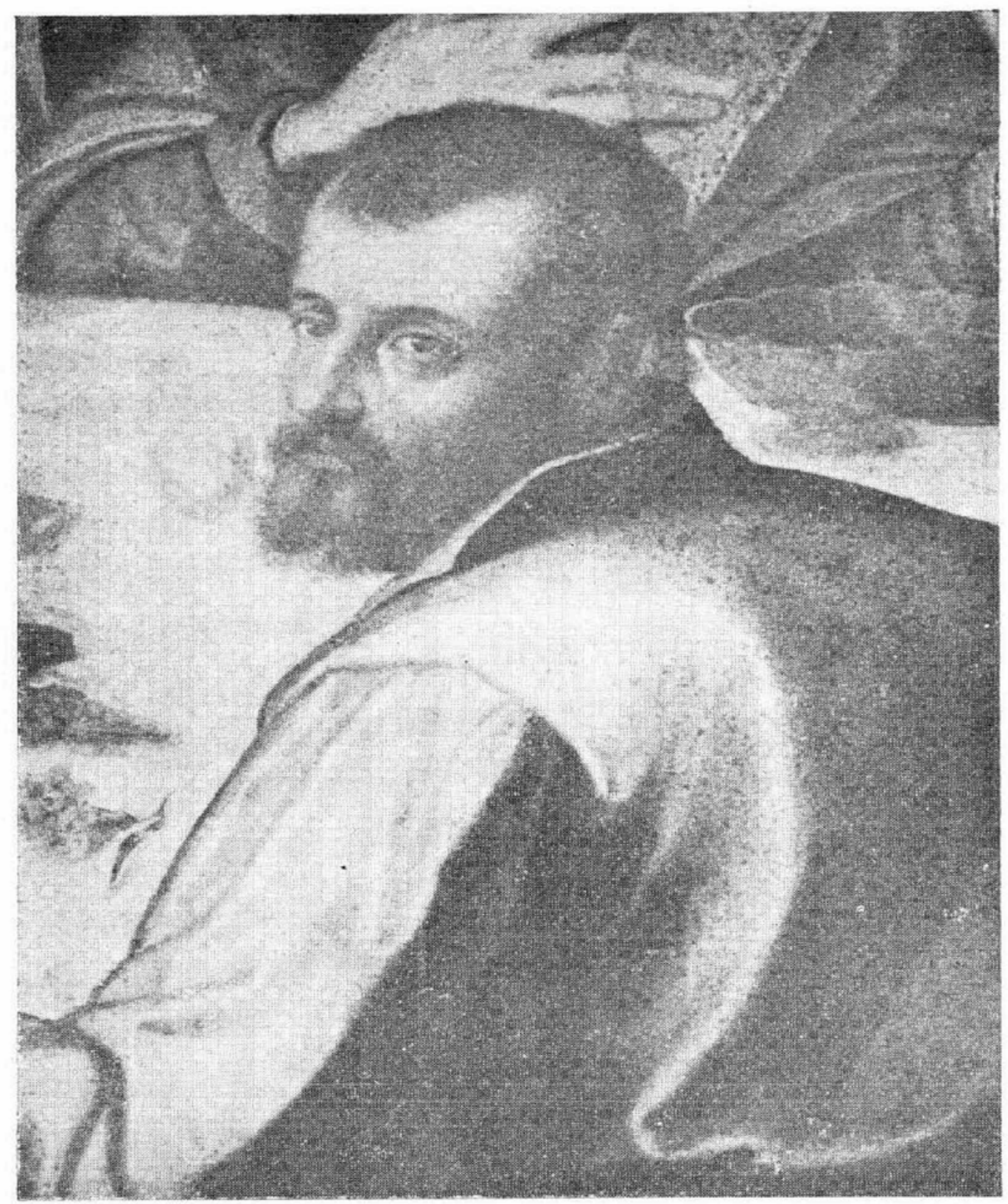

Figura 18. Pormenor de la obra anterior. 
DOI: http://dx.doi.org/10.22201/iie.18703062e.1983.51.1172

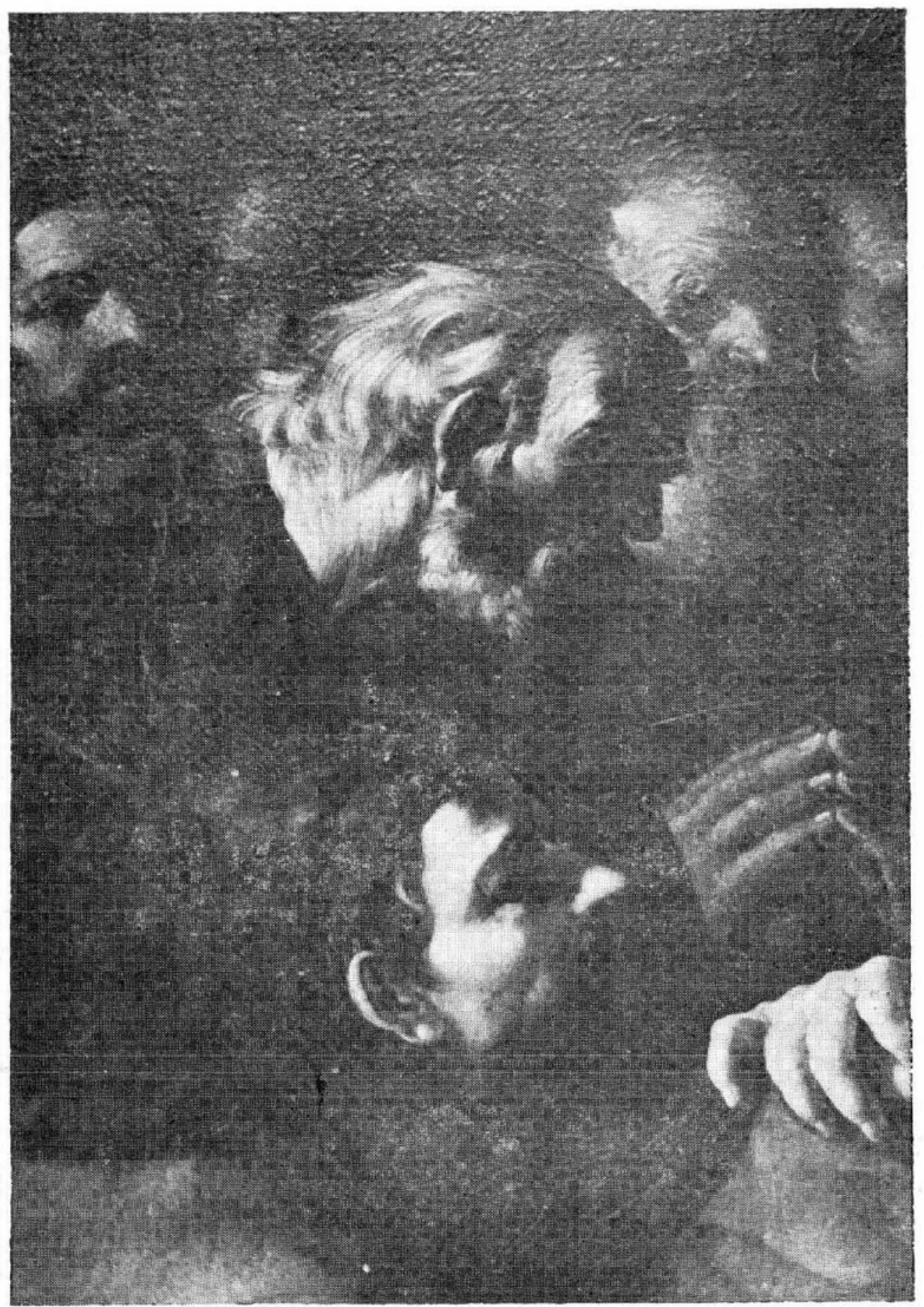

Figura 19. La incredulidad de Santo Tomais. Sebastián López de Arteaga. xvn. Pormenor. 


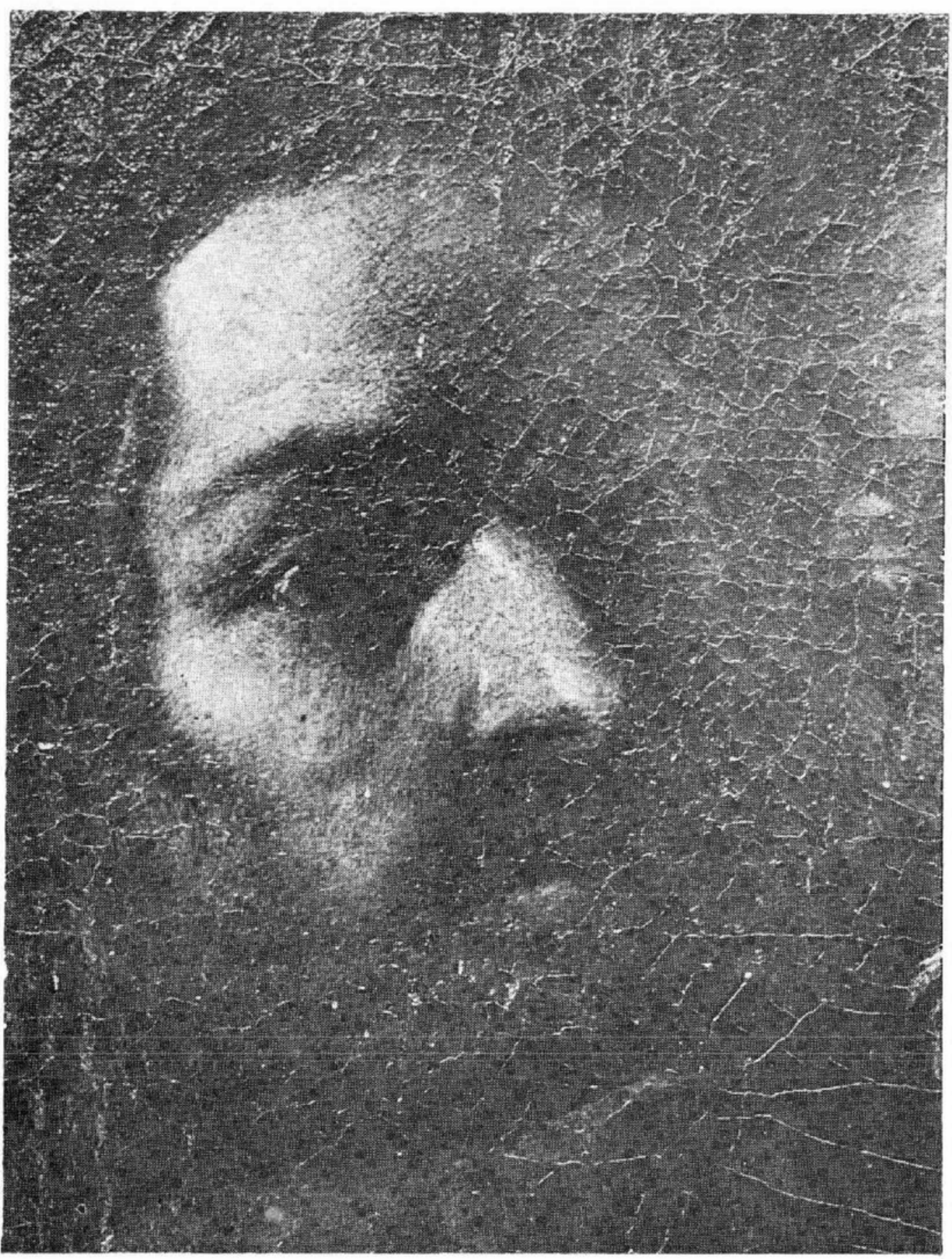

Figura 20. Pormenor de la obra anterior. 


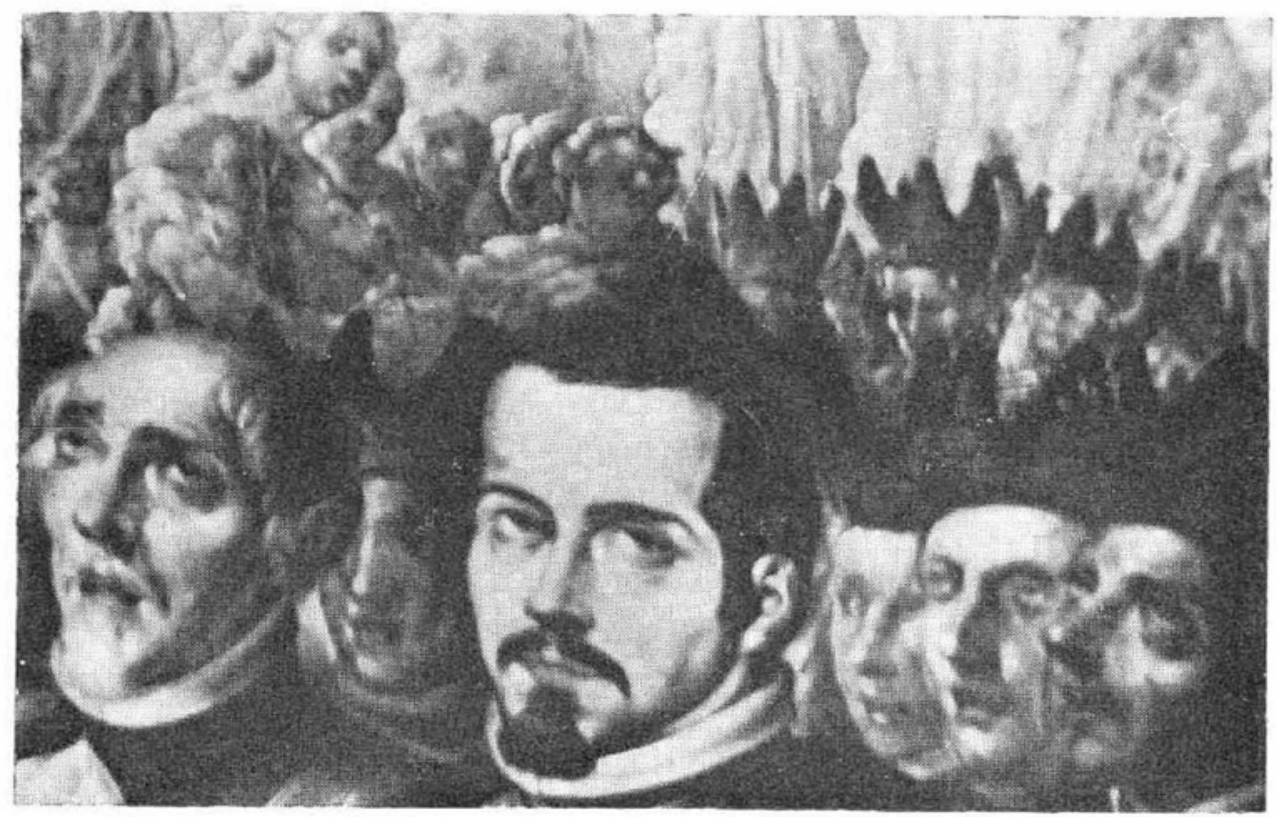

Figura 21. Autorretrato de Cristóbal de Villalpando. Pormenor de la Apoteosis de San Miguel. xvi. Sacristía de la Catedral Mctropolitana.

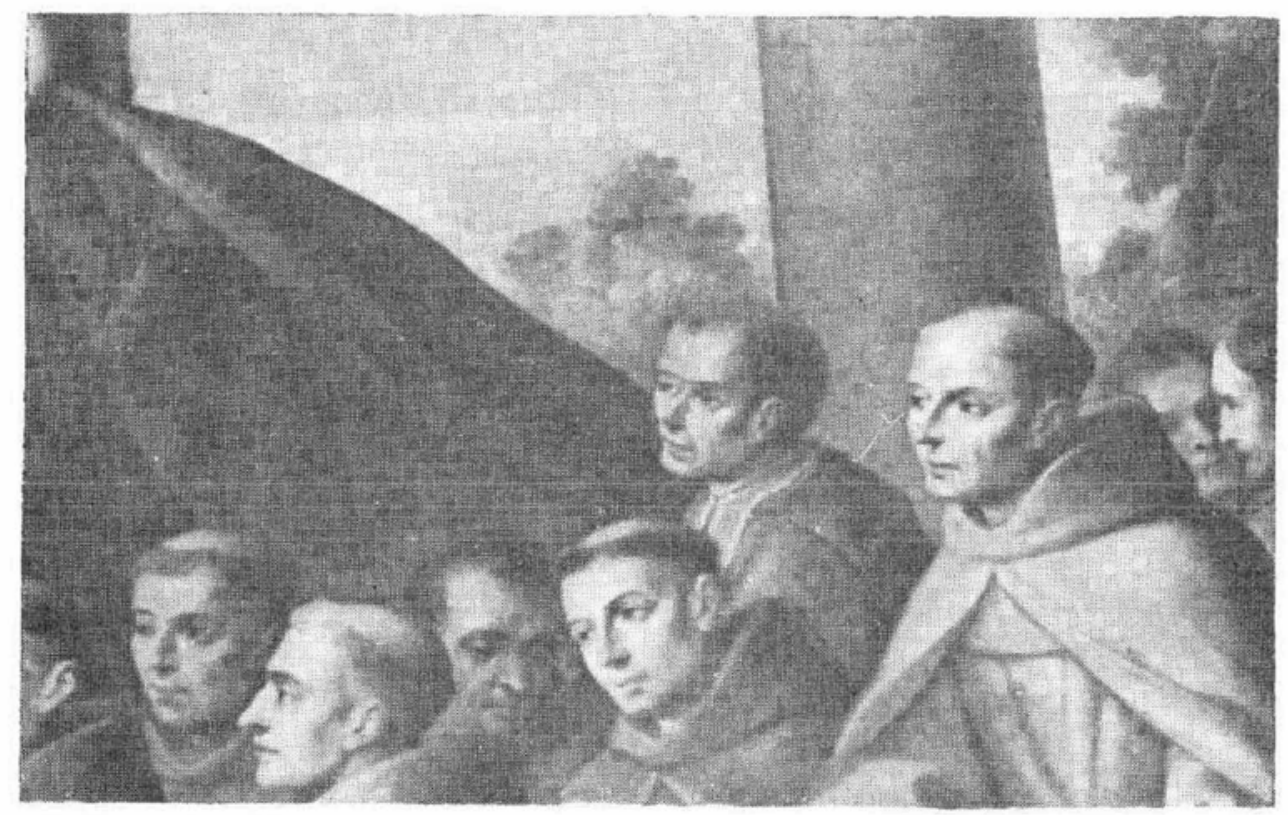

Figura 22. Autorretrato de Miguel Cabrera o de José de Ibarra, en Patrocinio de San Francisco. Museo de Guadalupe, Zacatecas. 
DOI: http://dx.doi.org/10.22201/iie.18703062e.1983.51.1172 


\section{Retratos de donantes}

La inclusión de retratos de donantes dentro de pintura de tema religioso fue costumbre que se empleó en Europa desde el siglo xv. Seguramente heredado de la escuela flamenca, este tipo de composición se implantó en la Nueva España desde temprana época y gustó definitivamente. Por lo general el donante, en la pintura novohispana guardó casi siempre un discreto lugar. Al parecer se siguió muy de cerca el modelo impuesto por el pintor español Francisco Pacheco (1564-1644) en su Inmaculada Concepción con Miguel Cid, ${ }^{2}$ en donde este donante aparece, retratado de busto, en el ángulo inferior izquierdo del lienzo, con un tamaño cuatro veces menor que el del cuadro. Por otra parte - dicho sea de paso- esta obra - que recrea al pie de la letra las recomendaciones que el propio Pacheco hace en su libro Arte de la Pintura, para representar este tema- parece haber servido directamente de modelo a las obras que con este asunto y con donantes, pintó el mexicano Juan Correa en la segunda mitad del siglo xvir. ${ }^{3}$ Sin embargo, existen por el momento tres o cuatro obras coloniales en las que los donantes están representados de tamaño natural o casi natural. Dentro de este tipo de obras, se ha consagrado en la pintura europea -como el retrato de donante por excelencia- el famoso cuadro conocido como la Virgen de Autun (Fig. I), pintada hacia 1425-35 por Jean van Eyck, en donde dicho personaje -aunque arrodillado- aparece en plano de igualdad formal y expresiva con la figura de la Virgen; uno frente al otro como en una visita. La escena tiene lugar en una pequeña galería desde donde se puede ver un precioso paisaje como fondo. Pero esta familiaridad jamás se dio en la pintura novohispana. Aun en las pocas pinturas que ofrecen representaciones de donantes de talla mayor, éstos se encuentran colocados, si no siempre en un plano secundario, sí en actitud de sometimiento, inferioridad y humildad respecto de las figuras sagradas.

El ejemplo más importante dentro de este tipo es -por el momentoel grupo de donantes formado por la familia Rincón Gallardo que se localiza en el templo de San José de Aguascalientes, que fue costeado por ella. En tamaño casi natural aparecen José Rincón Gallardo y García de Rojas, su esposa doña Francisca Josefa Calderón y Berrio y los niños Manuel -que después sería el nrimer marqués de Guadalupe-José María

2 La Peinture espagnole du siécle d'or de Greco à Velazquez Catálogo de la Exposición puesta en el Petit Palais de Parí de abril a junio de 1976, ficha 38.

3 Véase la "Tota Pulchra" que posee el Museo de Historia de Churubusco. 
y Guadalupe. Los personajes están colocados bajo el manto del Patro. cinio de San José, a uno de los lados, mientras en el otro se acomodan varios personajes eclesiásticos, entre los cuales no sería difícil llegar a identificar a algún personaje importante en relación con esa obra y esos tiempos. Con el mismo sentido compositivo, en la iglesia de La Merced de la ciudad de Atlixco, existe un gran lienzo firmado por Joaquín Magón -sobresaliente pintor poblano del siglo xrin-- que representa el Patrocinio de la Virgen de la Merced. Entre los personajes civiles que se protegen bajo su amplio manto, destaca una pareja -al parecer un matrimonio- elegantemente ataviada, que debe haber sido quien costeara la obra, pero cuyo nombre es aún desconocido.

Estas bellas obras barrocas merecen un detenido estudio iconográfico para desentrañar su completa significación; por el momento queden aquí anotadas como los ejemplos más importantes de este género, que ofrecen figuras de donantes en grupo y de talla casi natural, pues los retratos de donantes más comunes son individuales, según lo prueban los ejemplos que a continuación se comentan.

Posiblemente uno de los retratos más antiguos de donantes pueda ser el de Hernán Cortés que se conserva en el Museo de Chapultepec, por la expresión piadosa que tiene el rostro del conquistador. Dentro ya del siglo XvII se pueden citar varias obras muy interesantes y algunas de ellas incluyen retratos de niños donantes, costumbre que parece haber gozado de especial preferencia en la Nueva España. En primer lugar hay que mencionar el lienzo conocido como Ángel de la Guarda (Fig. 2), que ha sido atribuido a Alonso Vázquez y actualmente se reconoce como de Luis Juárez, según los estudios de Rogelio Ruiz Gomar. ${ }^{*}$ En esta preciosa pintura aparece de cuerpo entero la figura de un niño vestido con toda la formalidad del siglo xvir; calzón corto, medias con moño, ancha gola, etcétera. Se le ve pisando sobre un glabo terráqueo en actitud un tanto declamatoria. La gallarda figura de un ángel lo resguarda del mundo, del demonio y de la carne que aparecen representados a sus pies. El rostro del muchacho es un retrato magnifico que intenta expresar la viril energía ya latente en el infante. En La Porciúncula de José Juárez aparece, en el centro inferior de la composición un niño sentado, muy cabezón y de cuerpo mal proporcionado, es el retrato del hijo del donante que en una tablilla lleva escrito: A devoción de mi padre Alonso Gómez.

4 Rogelio Ruiz Gomax, El pintor Luis Judirez, su vida y su obra, tesis para optar por el grado de Maestro en Historia del Arte, UNAM, 1979. Inédita. 
Una bella obra anónima, Imposición de la casulla a san Ildefonso (Fig. 3), ofrece uno de los retratos femeninos mejor trabajados: una mujer de edad con una vela encendida cuyo rostro tratado con muy buen oficio realista, podría ser ejemplo de severa piedad.

Del famoso Juan Correa uno de los más proliferos pintores del siglo xvir se conocen tres donantes: una niña y dos hombres. La niña aparece a los pies del lienzo que representa a la Virgen del Pairocinio de Zacatecas (Fig. 4), que se conserva en el Museo de Guadalupe, Zacatecas. Extraordinariamente alhajada y trajeada, la niña une sus manos en señal de oración. Su rostro de bellas facciones y colorido, no deja de ofrecer un tratamiento convencional, por la artificialidad de la expresión que, como de costumbre, resulta demasiado estática para un rostro infantil. Mucho más sueltos, espontáneos y expresivos son los retratos de los donantes masculinos. Uno de ellos está en la representación de la Tota Pulchrá (Fig. 5), que forma parte de las colecciones del Museo de Churubusco. El donante es un hombre joven de larga cabellera oscura, ojos pequeños y claros, de mirada penetrante, que lleva golilla y anchas mangas con encajes negros y blancos. Junta también sus manos en actitud de oración. Su frente estrecha, ojos pequeños, nariz larga; en fin, todo el tratamiento de sus facciones es un buen intento de personalizar un rostro; es decir, de hacer retrato. Aunque al parecer de menor calidad, similares características pueden señalarse en la figura del donante que acompaña a la Inmaculada (Fig. 6), del convento de dominicas de Tudela, España, obra de 1701 .

Por el momento el retrato de donante infantil más valioso del siglo xvir lo constituye la representación de una niña mestiza, preciosamente ataviada con su traje nativo, sobre el que puede verse un velo de corte y material europeo. El bello rostro es una fiel representación del tipo racial resultante de la mezcla reciente de las dos razas: india y española (Fig. 7). Tal como tenía que ser en estos casos, la niña junta sus manos en actitud de oración y eleva la vista arrobada - desde el ángulo inferior derecho del cuadro hacia una imagen de San Antonio de Padua (Fig. 8) . La obra es anónima pero atribuible al buen oficio de Antonio Rodríguez.

La representación de donantes indios debe haberse hecho con bastante frecuencia, pues últimamente han aparecido varios en templos de provincia que si bien no tienen la alta calidad pictórica de la obra anterior, son testimonio de la importancia que tuvo el patronazgo de obras pías aun entre la clase indígena. Un ejemplo de pintura elemental de este género, de oficio rudimentario, pero al día en cuanto a la iconografía más impor- 
tante de su momento, ${ }^{\overline{5}}$ es una pequeña pintura - un óleo-que representa a Santa Rosa de Lima (Fig. 9), a cuyos pies se ve la diminuta india donante tan mal dibujada como la santa.

Ya dentro del siglo xvmr, se pueden citar como ejemplos sobresalientes, las niñitas arrodilladas, peinadas y vestidas como personas mayores -claro está- que acompañan la escena de Santa Ana enseñando a leer a la Vir. gen (Figs. 10 y 11), pintada por Nicolás Rodríguez Juárez y que se conserva en el Museo de la ciudad de Guadalajara. Del famoso Miguel Cabrera hay una dama joven donante (Fig. 12), con un ángel. La joven no tiene edad definida, luce severamente vestida y adornada con joyas bastante discretas en comparación con la cantidad y riqueza de joyas con que se retrataban las mujeres y las niñas de esa época. La composición es atípica porque ángel y donante aparecen en un ámbito abstracto, y la figura de la mujer, en sección áurea llega hasta la mitad de la altura del lienzo, pero aún así, el hecho de aparecer debajo de la figura del ángel de la guarda -que es quien se supone que está representado- le da el tono de sumisión a lo sagrado que se señaló al principio de estos párrafos.

Otras preciosas niñas donantes, que aparecen acompañando la escena de la Muerte de san Francisco Xavier, pintada por Francisco de León, pueden admirarse en el Museo de la ciudad de Guadalajara.

Característica importantísima de este género de retrato es el contraste de oficio y de expresión que ofrecen al espectador, porque destacan, en contraste en un mismo lienzo, las dos formas o tipos de expresión pictórica que se cultivaron en la pintura colonial: una directriz idealizada, dedicada al tratamiento de los personajes sagrados -dentro de ciertos convencionalismos específicos muy ceñidos- y el ejercicio de un realismo - de vieja prosapia aunque no depurado, salvo excepciones- que se dedicó a la representación de los seres humanos y que, como queda demostrado por algunos de los ejemplos que ilustran este artículo, alcanzó a veces, calidades de primera categoría, como por ejemplo en el mencionado retrato de la donante mestiza. Así, la necesidad de diferenciar el carácter sagrado del humano, dentro del mismo lienzo, produjo esta combinación peculiar en la que, además, se encuentran muchas de las más notables creaciones de retratos realistas - de verdaderos retratos hasta donde la estética del momento lo permitia- muchas veces superiores en oficio y expresión, a los retratos oficiales o de intención puramente social.

5 La devoción a santa Rosa de Lima comenzó en la Nueva España hacia 1668 y por ser esta santa americana, alcanzó una gran popularidad y significación. 


\section{El autorretrato}

El autorretrato -siempre tan interesante en cualquier época artística- seguramente por lo que significa de exaltación y proyección personal; valores contrarios al clima filosófico-religioso de la época, apenas si fue cultivado. Sin embargo, la pinacoteca colonial cuenta con algunos que enseguida se reseñan.

El más antiguo autorretrato que se conoce hasta ahora es el de Juan Rodríguez Juárez pintor activo entre 1692-1728 de pincelada suelta y bien logrados matices en el tratamiento del rostro, por su fino claroscuro y la expresión aguda de la mirada se coloca en el primer lugar de esta serie, como verdadero retrato, como búsqueda y logro en la representación de una personalidad anímica en particular. Esta obra es sin duda la que presenta más alta calidad en su género (Fig. 13).

Otro lienzo de casi igual valor pictórico es el autorretrato atribuido por algunos a Miguel Cabrera y por otros a José de Ibarra, sin que por el momento ninguna de las dos atribuciones puede tomarse como irrefutable. La pintura es de buen oficio, de pincelada suelta también y como en la anterior, los matices del rostro son bien logrados (Fig. 14)"

Existen por otra parte supuestos autorretratos de varios pintores pero dentro de composiciones con tema religioso. La lista comienza con dos de Baltazar de Echave Orio. Uno de ellos aparece en su precioso lienzo Pentecostés (Figs. 15 y 16), que pertenece a las colecciones del templo de La Profesa y el otro se puede admirar en la no menos bella obra $\mathrm{La}$ última cena (Figs. 17 y 18), que adorna el presbiterio del exconvento franciscano de Texcoco, hoy catedral. En ambas obras el parecido que ofrece el personaje con el grabado que se reconoce como retrato de dicho pintor, es efectivamente muy grande y en ambos casos también el carácter anímico que ostenta el viril rostro barbado, es el mismo. Por tanto, esta atribución es sin duda la más fundamentada. En segundo lugar, se cuenta con el autorretrato de Sebastián López de Arteaga en su Incredulidad de Santo Tomás (Figs. 19 y 20); en tercer lugar, el de Cristóbal de Villalpando en su enorme pintura Apoteósis de San Miguel (Fig. 21), que cubre uno de los muros de la sacristía de la catedral metropolitana; en último lugar, por orden cronológico, resta mencionar el que pudiera ser otro autorretrato de Miguel Cabrera o de José de Ibarra, en el lienzo anónimo titulado Patrocinio de san Francisco (Fig. 22) que se conserva en el Museo de Guadalupe, Zacatecas.

En todos estos casos destaca, dentro de la composición de tema reli- 
gioso la figura de un hombre con traje civil y rostro marcadamente diferente al de los personajes sagrados-gracias a un tratamiento de gusto realista, en unos casos más vigorosos que en otros- que mira hacia el espectador, desprendiendo su atención del tema religioso; características en las que se han fundamentado las atribuciones mencionadas. Para terminar hay que agregar que de todos estos supuestos autorretratos los que mayores probabilidades de autenticidad ofrecen, son los pintados por Echave Orio que, por cierto, en La última cena no sólo mira al espectador, sino que llama su atención volteando decididamente hacia afueta de la escena representada. 